\title{
Reducing Erosion Hazard on a Burned Forest in Oregon by Seeding
}

\section{E. WILLIAM ANDERSON AND LEE E. BROOKS}

Highlight: $A$ burned private forest was revegetated by seeding to grasses, legumes, shrubs, and trees. The sequence of events in carrying out this stabilization program provides a guideline for others handling similar situations; timeliness and ecological adaptation of species used is important. A field study (1969-72) compared results obtained on three ecological sites. A satisfactory vegetational cover was established by seeded grass the first year after seeding on all three sites, whereas natural revegetation did not provide satisfactory cover on an unseeded area in 4 years. Common legumes seeded for deer forage did not survive, indicating the need for additional study of species adaptation. Broadcasting tree seed was a failure. Seeded grasses apparently suppressed development of some native shrubs, which was detrimental to wildlife habitat. Herbage production on seeded areas was about four times greater than on the unseeded area. Two years of soil loss from seeded watersheds totaled less than 5 tons per acre as measured by the amount of sediment in debris basins. Fire-killed ponderosa pine snags were most susceptible to windthrow; grand fir was the least.

On July 5, 1968, lightning started the Snow Basin fire on private woodland in Wheeler County, Ore. The fire was brought under control by State Forestry Department crews on July 10 at a cost of about $\$ 200,000$. Four thousand acres of private forest had been devastated; soil on the entire area was essentially bare. The owners of the area pooled their resources and requested assistance in developing and applying a plan for rehabilitating the burn. One purpose of this paper is to relate the sequence of steps required to get this job done, which will act as a guideline for others who, faced with a similar situation, will need to avoid as much red tape and paperwork as possible in order to have seeding operations completed before rain causes soil crusting and reduces the chances of success. Another purpose is to report the effects of rehabilitation over a 4-year period and to compare the rehabilitated portion of one ecological site with a burned portion of the same site that was not treated.

\section{Description of Area}

The burned area includes portions of three ecological sites. The area between 2,800 and $3,400 \mathrm{ft}$ elevation is in the Pine-Sedge site; between 3,400 and 3,800 is in the Pinc-Mixed Fir site; and the upper portion of the burn, which lies between 3,800 and 4,400 ft, is in the Mixed Fir site. Average annual precipitation varies from about 15 to 22 inches for the burned area. The burn lies at about $45^{\circ}$ latitude and most of the burned area slopes southward.

Authors are state range specialist, Portland, Oregon (now retired) and district conservationist, Fossil, Ore. (now district conservationist, Baker, Ore.) Soil Conservation Service, U.S. Department of Agric ulture. Manuscript received August 24, 1974.
The Top soil series occurs over most of the burned area and is the principal soil of the two sites that occur above $3,400 \mathrm{ft}$ elevation. The surface layer of this soil is silt loam about 14 inches thick, the subsoil is silty clay loam about 20 inches thick, and the substratum is loam to a depth of about 50 inches. Hankins silty clay loam, which is about 7 inches thick over clay and fine textured sediments, is the principal soil of the Pine-Sedge site. Tolo silt loam, a deep ashy soil, occurs on north exposures, which constitute a minor portion of the area.

Perennial grasses, elk sedge (Carex geyeri), and forbs are abundant, and shrubs are important in the native plant communities of the Pine-Sedge and Pine-Mixed Fir sites under good ecological condition. The Mixed Fir site normally has a dense tree canopy under which herbaceous cover and shrubs are sparse. The burned area lies within an important spring-autumn range for deer and, since being seeded, is an important summer range for cattle and sheep.

\section{Sequence of Events}

Soon after the fire was extinguished, the Wheeler Soil and Water Conservation District requested the Soil Conservation Service (SCS) to help landowners of the area develop and apply a plan for rehabilitating the burn. The first meeting with the nine landowners was held July $21,1968$.

The rehabilitation plan, completed on September 11, was developed by the nine landowners with assistance from the SCS, Oregon Wildlife Commission, and Oregon Department of Forestry. The plan included salvage logging, seeding, debris basins, waterbars on all side roads and some main roads, and rest from grazing until after seeding establishment.

Salvage logging began in late July and all merchantable

Table 1. Mixtures of adapted species (lb/acre) used for seeding three ecological sites on a burned forest in Oregon.

\begin{tabular}{|c|c|c|c|}
\hline \multirow[b]{2}{*}{ Purpose of seeding and species used } & \multicolumn{3}{|c|}{ Ecological site } \\
\hline & $\begin{array}{l}\text { Pine- } \\
\text { Sedge }\end{array}$ & $\begin{array}{c}\text { Pine } \\
\text { Mixed } \\
\text { Fir }\end{array}$ & $\begin{array}{c}\text { Mixed } \\
\text { Fir }\end{array}$ \\
\hline \multicolumn{4}{|l|}{ Erosion control } \\
\hline Big bluegrass (Poa ampla) & 2 & & \\
\hline Crested wheatgrass (Agropyron desertorum) & 7 & & \\
\hline Hard fescue (Festuca ovina duriuscula) & 1 & 1 & \\
\hline Intermed iate wheatgrass ( $A$. intermedium) & & 8 & 5 \\
\hline Timothy (Phleum pratense) & & 1 & 1 \\
\hline Orchardgrass (Dactylis glomerata) & & & 4 \\
\hline Total & 10 & 10 & 10 \\
\hline \multicolumn{4}{|l|}{ Wild life forage } \\
\hline Bitterbrush (Purshia tridentata) & 0.60 & & \\
\hline Lana vetch (Vicia dasycarpa) & 0.32 & & \\
\hline Sainfoin (Onobrychis viciaefolia) & 0.63 & & \\
\hline White Dutch clover (Trifolium repens) & 0.32 & 1.6 & 0.38 \\
\hline Rose clover (T. hirturn) & & 2.8 & 1.80 \\
\hline Total & 1.87 & 4.4 & 2.18 \\
\hline
\end{tabular}


timber (11 million board feet) had been removed from the burned area by October 11 .

On August 5, a request for flood prevention emergency funds, available under Section 216 of the Flood Control Act of 1950, was made to the Administrator of SCS. The purpose was the installation of emergency runoff retardation and erosion control measures on the burned area. An allocation of $\$ 37,500$ was approved on September 3. These funds supplemented $\$ 11,000$ provided by the landowners and $\$ 7,633$ provided by the Oregon Wildlife Commission covering the total cost of installing the runoff retardation and erosion control measures.

A contract for 47,400 pounds of grass seed costing $\$ 19,182$ was awarded three companies on October 10 , and the seed was delivered by October 24. Legume and shrub seed was provided by the Oregon Wildlife Commission; tree seed was provided by Kinzua Lumber Company. The contract for helicopter services was awarded on October 17 at a cost of $\$ 3,737$ based on $\$ 0.59$ /acre for seeding grass and legumes, $\$ 0.58 /$ acre for seeding tree seed, and $\$ 0.36 /$ acre for spreading poisoned rodent bait.

Rodent bait was flown on the burned area on October 29. Seeding grasses and legumes began the next day and was completed November 2. Boundaries of the three ecological sites were identified by a series of aluminum markers to facilitate aerial seeding. Each site was seeded to a special mixture of adapted species as shown in Table 1. On November 3 , ponderosa pine (Pinus ponderosa) and Douglasfir (Pseudotsuga menziesii) tree seed was flown on about 800 acres with high tree-growing potential. The timeliness of the seeding operation in respect to the first significant autumn precipitation is important. Rain can crust the ash layer, or wash it away, thereby destroying the quality of the seedbed for broadcast seeding. In the case of Snow Basin seeding, a gentle 3-inch August rain, which is not typical for that area, did not cause crusting that lasted until seeding time. Except for 1 day during seeding, no more precipitation fell on the area until about 2 weeks after seeding. Then it snowed, and this snow cover persisted on the area until March. Moisture and temperature conditions were good for the Snow Basin seeding.

\section{Sampling Methods}

Herbage production for each site was determined at the end of the growing season by clipping plots $9.6 \mathrm{ft}$ in size. No attempt was made to randomize. Two steel-staked belt transects $100 \mathrm{ft}$ long and $1 \mathrm{ft}$ wide were established on each site. Annual changes in native and seeded species and other items were documented by:

1) Counting the number of plants of each species in each transect and averaging the two transects.

2) Using the above data to compute the percent composition of each species in the plant community.

3) Estimating the percent ground cover of each plant species, mosses and lichens, litter and mulch, and the percent of bare ground in the vicinity of each transect. This procedure results in a total that exceeds $100 \%$ when all items are added together, as illustrated by Table 2 , because bare ground occurs beneath the foliage of plants and the foliage of different species is often layered. It also reveals the dynamics of changes within a plant community with a minimum input of time and money and thereby adequately fulfilled the objective of this field study.

4) Rating each plant species according to its dominance in the physiognamy of the plant community in the immediate vicinity of each transect. A 5-digit system was used in which 5 represents the dominant species, 3 represents species that are common, and 1 represents species that are rare in the stand (Anderson and Poulton, 1958).

5) Counting the number of standing snags, by species, in each of seven diameter classes having 2 -inch increments from $0-2$ inches through 12 inches + on plots 100 feet square in which each transect was the centerline.

6) Taking photos of each transect at the time data were recorded (Fig. 1).

Plans to measure soil erosion on the watershed, using the procedure reported by Anderson (1974), proved impractical. Rills and other measurable evidence of soil movement did not develop. Apparently, the vegetational cover effectively controlled soil movement over much of the area. However, some erosion did occur in the heads of draws on steeper terrain and on a few logging roads; this material was deposited
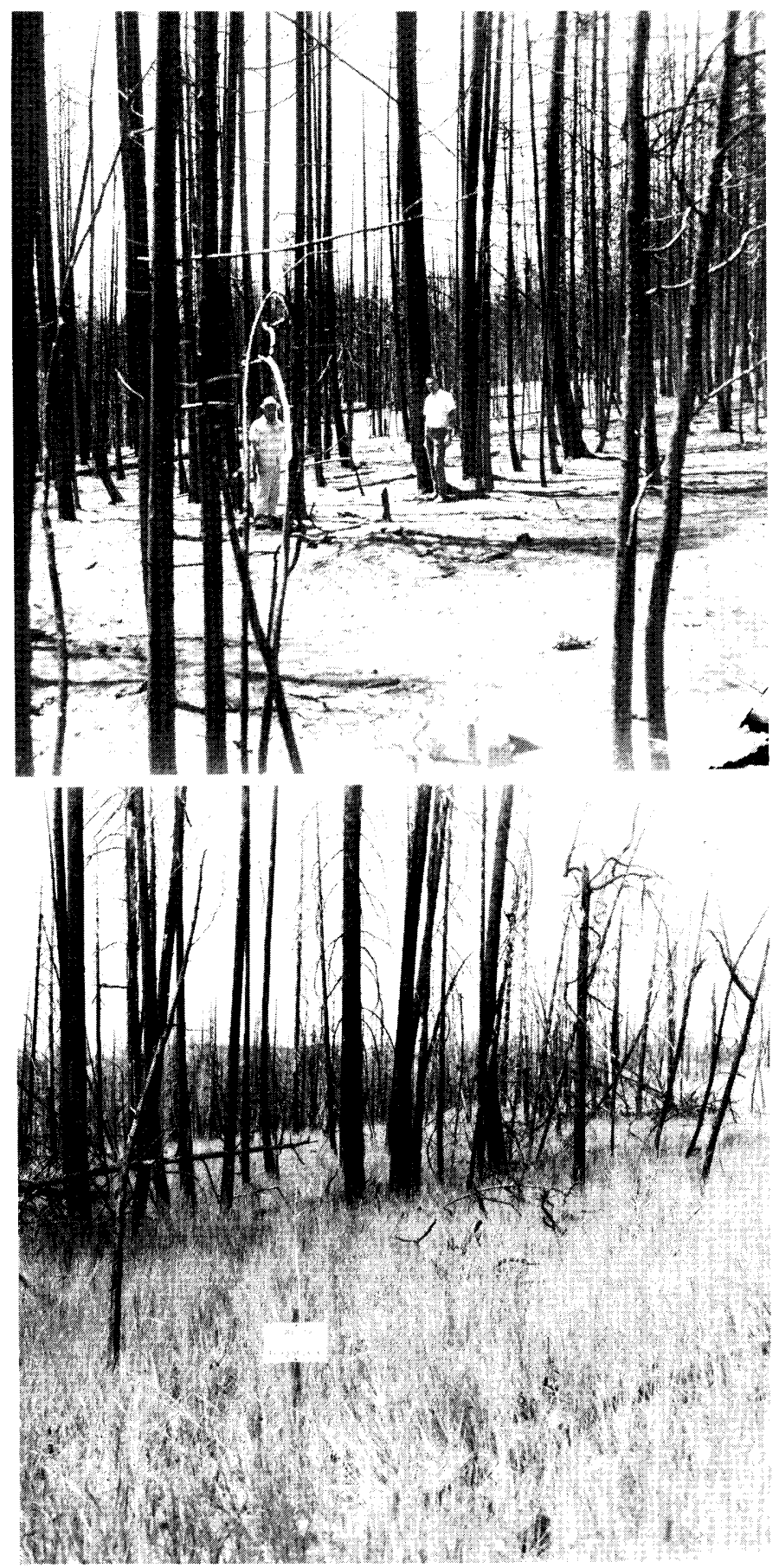

Fig. 1. The Pine-Mixed Fir site before and after seeding the watershed. 
where slope gradients flattened. At the end of the second year, erosion on the watershed was determined by measuring the amount of sediment that had been deposited in each of several debris basins which had been constructed during rehabilitation. The watershed acreage for each debris basin was determined and the loss of soil in tons per acre computed.

\section{Results}

Table 2 shows the changes that took place over a period of 4 years in percent ground cover of plant species, mosses and lichens, litter and mulch, and in the percent of bare ground on the three seeded sites and the unseeded area.

Bare ground was considerably less on the seeded area than on the unsecded area of the Pinc-Mixed Fir site the first 3 years following the burn (Fig. 2). Under seeded conditions, bare ground was occupied by vegetation at a lower rate and to a lesser degree on the Pine-Sedge site than on either of the other sites. The occupation of bare ground by vegetation occurred at the highest rate and to the greatest degree on the most moist Mixed Fir site. It can be concluded that seeding the burned area produced vegetational cover which reduced the erosion hazard significantly during the first 3 years following the burn.

Mosses and lichens had become established on the Mixed Fir site by the second year following seeding but did not occur in a like manner on the two drier sites. It is not known whether they occur normally on these sites under good ecological condition; however, the decline in amount of mosses and lichens from 1970 through 1972 indicates that they might not tolerate herbaceous cover.

Litter and mulch, important items in watershed quality, developed more rapidly and to a greater degree on the seeded

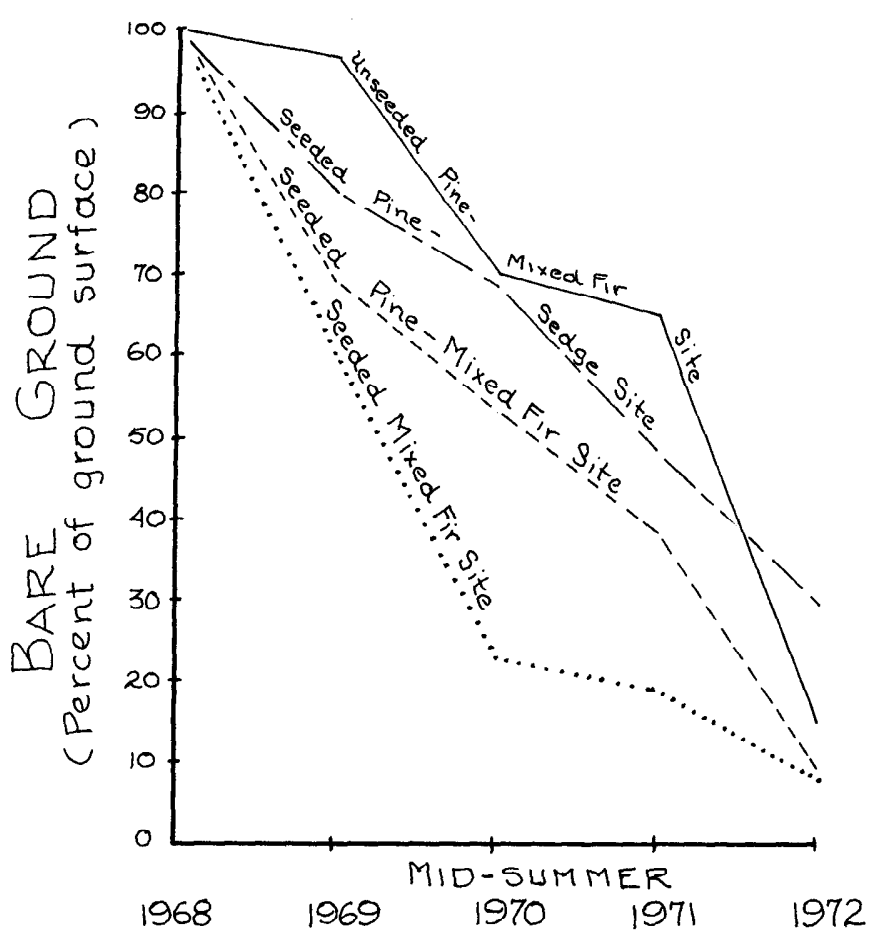

Fig. 2. Rate and degree of reduction in bare ground due to seeding.

than on unseeded area of the Pine-Mixed Fir site. The rate and degree of development was less on seeded areas of the Pine-Sedge site and greatest on the most moist Mixed Fir site.

Species used in seeding mixtures usually display their range of adaptation to certain sites; some do not survive, others are

Table 2. Changes in ground cover (\%) of plant species, mosses and lichens, litter and mulch, and amount of bare ground (\%) on unseeded and seeded burned forest in Oregon.

\begin{tabular}{|c|c|c|c|c|c|c|c|c|c|c|c|c|c|c|c|c|}
\hline \multirow[b]{3}{*}{ Items } & \multicolumn{4}{|c|}{ Unseeded } & \multicolumn{12}{|c|}{ Seeded } \\
\hline & \multicolumn{4}{|c|}{ Pine-Mixed Fir } & \multicolumn{4}{|c|}{ Pine-Sedge } & \multicolumn{4}{|c|}{ Pine-Mixed Fir } & \multicolumn{4}{|c|}{ Mixed Fir } \\
\hline & 1969 & 1970 & 1971 & 1972 & 1969 & 1970 & 1971 & 1972 & 1969 & 1970 & 1971 & 1972 & 1969 & 1970 & 1971 & 1972 \\
\hline Bare ground & 97 & 70 & 65 & 15 & 80 & 68 & 48 & 30 & 68 & 53 & 39 & 9 & 60 & 23 & 19 & $\sqrt{8}$ \\
\hline Mosses and lichens & 0 & 0 & $T$ & 0 & 0 & $\mathrm{~T}$ & $\mathrm{~T}$ & 0 & 0 & 0 & $\mathrm{~T}$ & 0 & 0 & 10 & 8 & 2 \\
\hline Litter and mulch & 2 & $\mathrm{~T}$ & 2 & 25 & $\mathrm{~T}$ & $\mathrm{~T}$ & 3 & 10 & 13 & 4 & 23 & 35 & 28 & 20 & 23 & 43 \\
\hline \multicolumn{17}{|l|}{ Seeded species } \\
\hline Bluegrass, big & & & & & 10 & 9 & 22 & 14 & & & & & & & & \\
\hline lèscue, hard & & & & & 2 & 2 & 7 & 2 & 1 & 2 & 9 & 6 & & & & \\
\hline Whea tgrass, crested & & & & & 2 & 5 & 9 & 8 & & 2 & 2 & 1 & & & & \\
\hline Timothy, climax & & & & 1 & & $\mathrm{~T}$ & 1 & & 3 & 6 & 13 & 10 & 11 & 5 & 10 & 8 \\
\hline Wheatgrass, intermed iate & & $\mathrm{T}$ & 1 & 2 & & & & & 8 & 20 & 38 & 35 & 2 & 21 & 20 & 14 \\
\hline Orchardgrass & & & & & & & & & & & & & 18 & 43 & 30 & 32 \\
\hline Clover, white Dutch & & & & & 4 & 1 & 0 & 0 & $\mathrm{~T}$ & $\mathrm{~T}$ & 0 & 0 & 1 & $\mathrm{~T}$ & 0 & 0 \\
\hline Sainfoin & & & & & 2 & 2 & 1 & 2 & & & & & & & & \\
\hline Vetch, lana & & & & & 1 & 0 & 0 & 0 & & & & & & & & \\
\hline Clover, rose & & & & & & & & & $\mathbf{T}$ & $\mathrm{T}$ & 0 & 0 & 0 & 0 & 0 & 0 \\
\hline Bitterbrush & & & & & 1 & 1 & 3 & 2 & & $\mathrm{~T}$ & & $\mathrm{~T}$ & & & & \\
\hline \multicolumn{17}{|l|}{ Natural species } \\
\hline Annual grasses & $\mathrm{T}$ & $\mathbf{T}$ & 1 & 16 & 1 & $\mathrm{~T}$ & $\mathrm{~T}$ & $\mathrm{~T}$ & 8 & 14 & 2 & 2 & 1 & $\mathrm{~T}$ & 2 & $\mathrm{~T}$ \\
\hline Annual forbs & 1 & 19 & 46 & 4 & 7 & 7 & 9 & 17 & 9 & 4 & 2 & $\mathrm{~T}$ & 6 & 3 & 2 & 2 \\
\hline Perennial grasses & 1 & 1 & 7 & 4 & 2 & 0 & 0 & $\mathrm{~T}$ & 4 & 2 & 3 & 1 & 3 & 2 & 2 & $\mathrm{~T}$ \\
\hline Perennial forbs & 4 & 3 & 2 & 18 & 7 & 7 & 6 & 7 & 8 & 3 & 3 & 7 & 10 & 3 & 5 & 5 \\
\hline Oregongrape, low & 1 & 4 & 2 & 7 & & & & & $\mathbf{T}$ & 0 & 0 & $\mathrm{~T}$ & $\mathrm{~T}$ & $\mathrm{~T}$ & 2 & $\mathrm{~T}$ \\
\hline Rose & 1 & 5 & 4 & 5 & $\mathrm{~T}$ & 1 & 1 & $\mathbf{T}$ & $\mathbf{T}$ & $\mathbf{T}$ & $\mathrm{T}$ & 0 & $\mathrm{~T}$ & $\mathrm{~T}$ & $\mathrm{~T}$ & 1 \\
\hline Snowberry, common & 3 & 15 & 15 & 10 & 1 & 0 & 2 & 1 & $\mathrm{~T}$ & $\mathrm{~T}$ & 0 & $\mathrm{~T}$ & 2 & 1 & 4 & 5 \\
\hline Snowbrush & 1 & 2 & 2 & 2 & 2 & 6 & 19 & 22 & 1 & 3 & 2 & 5 & 1 & $\mathrm{~T}$ & $\mathrm{~T}$ & $\mathrm{~T}$ \\
\hline Other shrubs & & & 1 & $\mathrm{~T}$ & $\mathrm{~T}$ & $\mathrm{~T}$ & 2 & 1 & & & & & $\mathrm{~T}$ & 0 & 0 & 0 \\
\hline Total vegetational cover & 12 & 49 & 81 & 70 & 43 & 41 & 79 & 75 & 44 & 57 & 75 & 67 & 56 & 80 & 78 & 68 \\
\hline Total perennial grass & 1 & 1 & 8 & 7 & 16 & 16 & 39 & 24 & 16 & 32 & 65 & 53 & 34 & 71 & 62 & 54 \\
\hline
\end{tabular}


weak or strong in the way they develop in the stand on certain sites. For example, within 4 years following this seeding, crested wheatgrass seeded only on the Pine-Sedge site was beginning to spread into the more moist Pine-Mixed Fir site. Timothy, seeded only on the Pine-Mixed Fir and Mixed Fir sites, began spreading slightly into the drier Pine-Sedge site. Intermediate wheatgrass and timothy appear to be spreading into the unseeded area, thus indicating a strong performance on the Pine-Mixed Fir site.

Generally, the performance of all seeded grasses was sufficiently strong on the sites on which they were seeded to substantiate the contention that, whenever practical, a seeding mixture should be designed for a particular ecological site and for the uses to be made of the seeding,

Except for sainfoin, the legumes seeded to benefit wildlife failed to survive. Sainfoin seeded in the Pine-Sedge site persisted in the stand in a satisfactory amount, particularly since it was seeded so lightly $(0.63 \mathrm{lb} / \mathrm{acre})$. Regretably, sainfoin was not seeded on all three sites to demonstrate its performance under varying ecological conditions.

Bitterbrush is a native to the Pine-Sedge site on which it was seeded, and its performance on that site to date is satisfactory. A small plot seeding of snowbrush (Ceanothus velutinus) was not discernible because of the abundant seedlings of native snowbrush that germinated over much of the burned area the first year after the fire. This small plot also included seed of squawcarpet (Ceanothus prostratus), which is not native to this area, and only one seedling was observed; after the first year there were none.

The principal native shrubs that grow on all three sites in this burn were the ones that constitute most of the ground cover shown for native shrubs in Table 2. They were low Oregongrape (Berberis repens), rose (Rosa spp.), common snowberry (Symphoricarpos albus), and snowbrush.

Native shrubs developed much more abundantly on the unseeded area than on the seeded areas of the Pine-Mixed Fir site. This indicates that they might have been suppressed by the seeded grasses. Reducing the shrub cover on an important spring-autumn deer range might be detrimental, depending upon the species affected. In this case, the species suppressed were low Oregongrape, rose, and common snowberry; the last two have value as deer and elk forage in spring-summer-autumn (Edgerton and Smith, 1971). Snowbrush, a valuable deer-forage species, apparently was not suppressed by seeded grasses.

Reducing erosion hazard and stabilizing the watershed at an early stage was the major objective of this seeding; wildlife and livestock forage are among the fringe benefits incorporated into the planned rehabilitation. As previously stated, soil movement on the transects the first year following seeding was immeasurable using the proposed method. Some soil movement took place on steeper areas and on some roads. Most of this material appeared to be deposited on the seeded watershed before it reached debris basins. Measured sediment in debris basins was equivalent to less than 5 tons per acre soil loss from the watershed, which is a small soil movement from a burn such as this. Unfortunately, comparable data on the unseeded area could not be obtained because it was a small, gently sloping spot in the watershed surrounded by seeded areas.

Plans to obtain herbage production data were disrupted; some data were collected each year but this was inadequate. Several observations can be made, however, which support
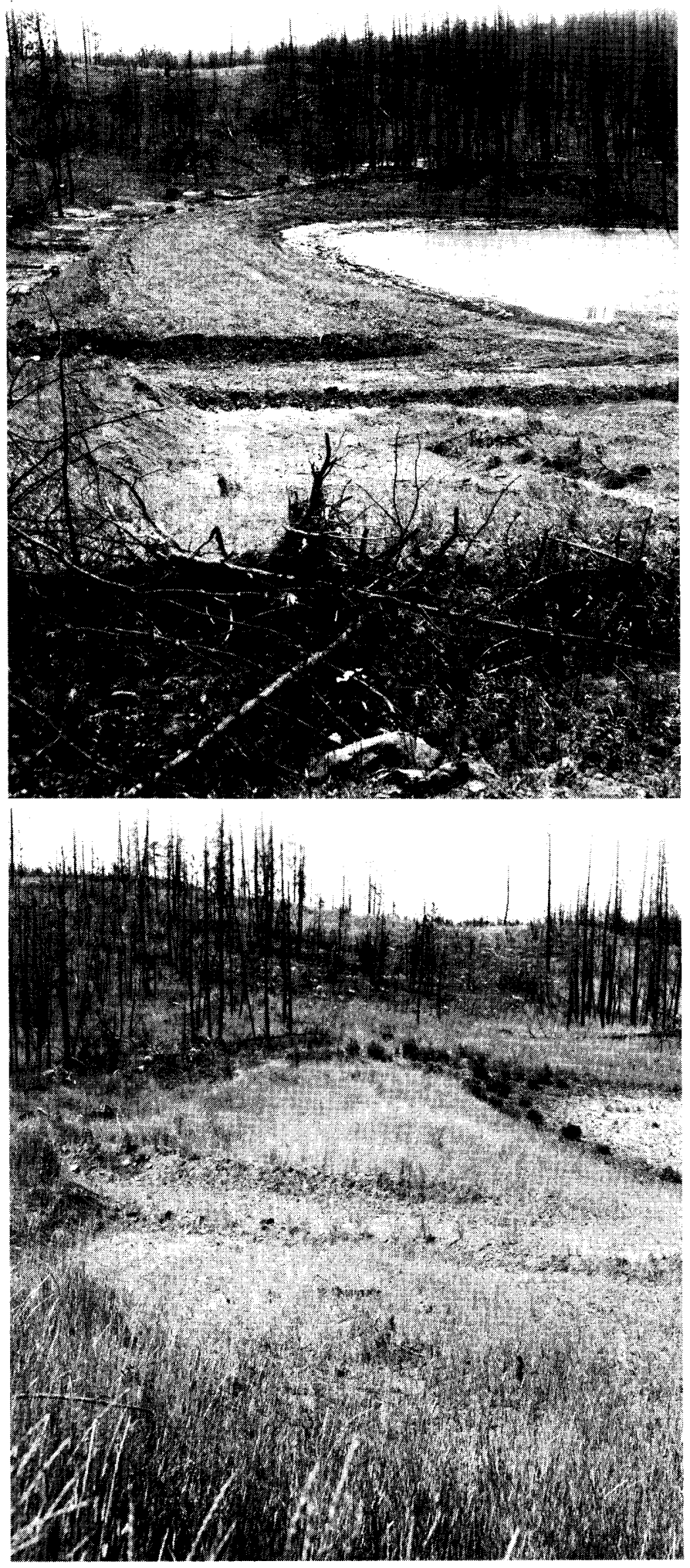

Fig. 3. A debris basin before and after seeding the watershed showing the lack of runoff following stabilization of the watershed.

\section{previous experiences:}

1) The seeded area produced about four times as much herbage as the unseeded area of the Pine-Mixed Fir site.

2) Production was highest on all sites in 1970 , it declined in 1971 to about $75-80 \%$, and in 1972 to about $60-80 \%$; 
production of the more moist Mixed Fir site declined the least.

3) Virtually all herbage on seeded areas consisted of seeded perennial species and native shrubs, whereas herbage on the unseeded area consisted mainly of native annuals and shrubs.

Practically all trees on the burned area wcre killed by fire. Those 12 inches in diameter breast high and larger were salvaged as soon as possible by the owners. Records kept on standing snags to determine the character of windthrow showed:

1) Snags began to fall noticeably during the third year on the Pine-Mixed Fir and Mixed Fir sites and during the fourth year on the Pine-Sedge site, which is the driest of the three.

2) Ponderosa pine showed the greatest susceptibility to windthrow during the 4 years; grand fir was the most

\section{resistant.}

Only one Douglasfir seedling resulting from sown seed was observed on the burned area. In 1970, the Kinzua Lumber Company, which owns about half the burned area, made a trial planting of ponderosa pine. In subsequent years, Kinzua has expanded this planting program with the intention to reforest the soils that have good tree-growing potential.

\section{Literature Cited}

Anderson, E. William, and Charles E. Poulton. 1958. Collection of ecological data for soil-site correlation in Oregon. Published jointly by U.S. Dep. Agr., Soil Conserv. Serv. and Oregon State Univ. 17 p.

Anderson, E. William. 1974. Indicators of soil movement on range watersheds. J. Range Manage. 27:244-247.

Edgerton, Paul J., and Justin G. Smith. 1971. Seasonal forage use by decr and elk on the Starkey Experimental Range, Oregon. U.S. Dep. Agr., Forest Serv. Res. Pap. PNW-112, 12 p. Pacific NW Forest and Range Exp. Sta., Portland, Oregon. 